\title{
Emphasizing the Concept of Spiritual Intelligence from Islamic and Western Perspectives on Multiple Intelligence
}

\author{
Syuzianti Shaari' ${ }^{1}$ Mohd Effendi Ewan Mohd Matore ${ }^{2}$ \\ ${ }^{1}$ Sekolah Kebangsaan Leftenan Adnan, Sungai Ramal Luar, Kajang, Malaysia \\ ${ }^{2}$ Centre of Educational Planning and Policy, Faculty of Education, Universiti Kebangsaan Malaysia, Bangi, Malaysia \\ Email: p91723@siswa.ukm.edu.my, effendi@ukm.edu.my
}

How to cite this paper: Shaari, S., \& Matore, M. E. E. M. (2019). Emphasizing the Concept of Spiritual Intelligence from Islamic and Western Perspectives on Multiple Intelligence. Creative Education, 10, 2815-2830.

https://doi.org/10.4236/ce.2019.1012208

Received: October 21, 2019

Accepted: November 25, 2019

Published: November 28, 2019

Copyright $\odot 2019$ by author(s) and Scientific Research Publishing Inc. This work is licensed under the Creative Commons Attribution International License (CC BY 4.0).

http://creativecommons.org/licenses/by/4.0/

(c) (i) Open Access

\begin{abstract}
Various intelligence theories have been put forward in the West, including the most popular is the Multiple Intelligences (MI) proposed by Gardner (1983). MI theory includes eight constructs, i.e. verbal-linguistic intelligence (VL), logical-mathematical intelligence (LM), visual-spatial intelligence (VS), bodily-kinesthetic intelligence (BK), musical intelligence (MZ), interpersonal intelligence (IE), intrapersonal intelligence (IA) and naturalist intelligence (NR). Spiritual intelligence (SI) is the ninth intelligence introduced by Gardner (1999). This concept paper aims to compare the theory of MI by the West with Islamic perspectives in the context of spiritual intelligence. Researchers feel called upon to discuss this issue as the construction of the MI is still being debated among Western scholars. It was also has been widely discussed among Islamic scholars. In the Islamic perspective, the MI constructions are based on the Quran and the As-Sunnah which consists of seven domains, namely, the soul (al-ruh), qalbu (al-qalb), heart (al-nafs), intellect (al-'aql)), faith, practice and morals. Discussions of spiritual intelligence constructs which are one of the constructs in MI theory, are needed to gain a deeper understanding. The discussion must be emphasizing on how the implementation of MI theory for teaching and learning processes can achieve its objectives. In addition, the comparative analysis of spiritual intelligence between Western and Islamic concepts will highlight the convergence of interesting ideas in MI theory to enhance spiritual intelligence looks more contextualized with the predominantly Muslim Malaysian community.
\end{abstract}

\section{Keywords}

Multiple Intelligence, Spiritual Intelligence, Western and Islamic Perspectives 


\section{Introduction}

More recently, the concept of multiple intelligences has been widely discussed in the field of education. Many people think of the concept of various intelligences emerging earlier in the Western world. In fact, Muslim scholars and intellectuals in ancient times pioneered this concept without using the same terms. Pasiak (2008) explained that various theories of intelligence, including the theory of MI have been discussed in the Quran since 1400 years ago. There are not many previous studies that describe the comparison of MI between these two beliefs, especially in MI construct. Thus, this paper is a researcher's attempt to compare the concept of multiple intelligences according to the West with Islamic perspectives in the spiritual aspects. These comparisons in turn can lead to an interesting idea in further strengthening the MI construct to be implemented in Malaysian society, where the majority of the population is Muslim.

\section{Multiple Intelligences from Western Perspectives}

The theory of intelligence began to exist in the field of modern psychology in the late 19th century. The field of modern psychology is strongly influenced by the concept of human intelligence. Early theories of human intelligence were pioneered by Francis Galton (Cohen \& Swerdlik, 2009). However, the theory of human intelligence is not able to reach the affective domain of humans because it is limited to the functions of cognitive operations only. Meanwhile, Spearman (1904) debated the concept of intelligence based on Two-Factor Theory. This theory explains that all human intelligence has an overlap called the "g" factor (general) (Arifin, Arifin, \& Makki, 2008). This factor refers to the intelligence of the individual due to genetic or hereditary factors. In addition, each of these intelligence abilities has a " $s$ " (specific) factor as a complement of intelligence. In other words, the " $\mathrm{s}$ " (specific) factor complements the "g" (general) factor in describing the individual's intelligence holistically. The "s" (specific) factor refers to an individual's intelligence caused by only one factor.

However, Gardner from Harvard University, USA in the 1980s, developed a theory, namely the MI theory. This theory denies assumption that human intelligence is only focused on one factor. Instead, human intelligence can be developed either by the environment, education and experience. Gardner (1983) asserts that every intelligence is separate and independent of each other as a person may excel in a particular field of expertise, but poor in other areas of intelligence. Initially, the theory of Multiple Intelligences proved that all individuals had seven types of intelligence, namely Verbal Linguistics (VL), Logical Mathematical (LM), Visual Spatial (VS), Bodily-Kinesthetic (BK), Music (MZ), Interpersonal (IE), and Intrapersonal (IA). Gardner (1999) redefined the meaning of intelligence and subsequently introduced the eighth intelligence, namely the naturalist (NA), referring to the ability to identify and categorize living species in the environment. In addition, he also identified the existence of the ninth intelligence, namely the "spiritual intelligence" (SQ), which was later replaced by the "existential intelligence" which he called "intelligence of big questions". 
Each type of intelligence in multiple intelligence has its own meaning. Gardner (1983) defined Verbal Linguistic Intelligence (VL) as the ability to speak, write, remember information, persuade others and communicate about the language itself. Logical Mathematical Intelligence (LM) is the ability to use numbers effectively, argue wisely, to understand the set of basic numbers, the principles of cause and effect and the ability to anticipate an event. Visual Spatial (VS) is the ability to detect and visualize shapes, spaces, colors and lines as well as present visual and spatial ideas graphically. Kinesthetic Intelligence (KI) is the ability to use the body to express ideas, feelings and solve problems, including physical skills such as coordination, elasticity, speed and balance. Music Intelligence (MZ) is the ability to detect rhythms and songs, recognize, differentiate or change the rhythm and tempo of a melody. Interpersonal intelligence (IE) refers to the ability to understand other people's feelings, motivations, habits or desires and the ability to act effectively toward others practically. Intrapersonal Intelligence (IA) is the ability to understand oneself in terms of strengths, weaknesses, desires or wishes, the same or different skills with others and able to deal with feelings, civilized manners and control anger or sadness. The last intelligence, namely the Naturalist Intelligence (NA) is the ability to recognize and categorize plants, minerals, and animals, including grass and rocks, flora and fauna and the ability to recognize cultural artifacts in terms of clothing and food (Gardner, 1993). Another intelligence that not involved in this discussions is Adversity Quotient or being called as Adversity Intelligence from some researcher. This intelligence related to resilience and how well of someone facing challenges in their life. Many research related to AQ in Malaysia have been done (Effendi \& Matore, 2019a, 2019b; Effendi, Matore, Ahmad Zamri, \& Nordin, 2018; Effendi, Matore et al., 2018).

In short, the concept of multiple intelligences from the perspective of the West is based on nine types of constructs of intelligence, namely Verbal Linguistics (VL), Logical Mathematical (ML), Visual Spatial (VS), Bodily-Kinesthetic (BK), Music (MZ), Interpersonal (IE), Intrapersonal (IA), Naturalist Intelligence (NA) and Spiritual Intelligence (SI). Gardner has clearly outlined each type of intelligence. However, Arifin, Arifin, \& Makki (2008) said that Gardner has not yet confirmed the construction of this MI. This view was further reinforced by Maryam Safara \& Bhatia (2013) who explained that Gardner rejected MI constructs because there was no experimental investigation of psychology or psychometric findings.

\section{Multiple Intelligences from Islamic Perspectives}

In fact, Gardner's MI theory was originally pioneered by Muslim scholars of old, but in different context. For example, Ibn-Khaldun had previously touched on several types of intelligence, namely al-aql at-Tamyizi (discerning intellectual), al-aql at-Tajribi (experimental intellectual) and al-aql an-Nazari (speculative intellectual) (Gamal, 2003). Al-aql at-Tamyizi is the intellect that senses the things that are outside of the person and the characteristics of them so that one can 
take advantage or avoid the danger of such objects. Al-aql at-Tajribi is a person's ability to distinguish good and bad through interaction among people and can make quick decisions about what must be done and must be avoided in daily interactions. On the other hand, al-aqlan-Nazari is an idea or desire that has nothing to do with action (Gamal, 2003). In short, Ibn-Khaldun believes that humans learn through experience, senses and intellectual process.

In addition, Ariffin \& Ismail (2007) also stated that the MI theory presented by Gardner is similar to the concept of the Prophet's education, which respects individual differences. For example, He was once asked by one of His companions about a good deed that is most pleasing to God. He answered, "prayer in time", when the same question was asked by his other Companions, he replied, "be kind to both parents". That is how he responds to the circumstances and situations of the individuals who asked the question (Ariffin \& Ismail, 2007).

This statement is in line with Yusuf Al-Qardhawi (2003) who argued that a good and effective teacher is a teacher who can impart knowledge according to the level of student development. He has listed five facts show that the prophet SAW was an educator who took into account individual differences in delivering his teachings, 1) He gave appropriate advice on the differences of each individual who sought advice. 2) Provide different answers to the same questions tailored to the individual asking the questions. 3) Showed different behaviors and attitudes appropriate person to get along with him. 4) Conveyed a command and law of a suit that is tailored to the ability of the person receiving it. 5) Imposed punishment and accept a person's attitude but does not accept it from another person because of the circumstances of the situation. This is reinforced by the Quran, saying that "It is He who has sent among the unlettered a Messenger from themselves reciting to them His verses and purifying them and teaching them the Book and wisdom, although they were before in clear error." (Al-Quran, Al-Jumuah 62:2).

This verse describes the personality of the Prophet SAW who was also a great and mighty man (protected from sin), but still a human being who could make mistakes and weaknesses such as "Ummiy", that is, unable to read and write. However, he was endowed with various other intelligences, such as Bodily-Kinesthetic Intelligence (BK), Interpersonal Intelligence (IE) and Intrapersonal Intelligence (IA). The most important intelligence that reveals the greatest personality of the prophet SAW is the spiritual aspect or SI. This is evidenced by the power of his message across time and geographical boundaries.

\section{Spiritual Intelligence}

Spiritual Intelligence (SI) is a term that is gaining popularity among academics and professionals, particularly in the fields of philosophy, religion and psychology. Effendi \& Matore (2015) explained that spiritual is derived from the Latin word, "spiritus" which means the principle of importance in an organism. In addition, the " $\mathrm{S}$ " also derives from the word "sapientia" which means intelli- 
gence of wisdom (Effendi \& Matore, 2015). In Islam, SI is derived from the Quran and Sunnah. Whereas in the West, the SI was introduced by a pair of husband and wife scientists, Danah Zohar and Ian Marshall in early 2000. Zohar \& Marshall (2000) argued that the introduction of self, especially self-awareness, is the inner consciousness of the brain. According to him, the process takes place in the brain alone, without the influence of the senses and the outside world that make up the true human consciousness.

Currently, there are many studies on SI that have been conducted both domestically and abroad (Emmons, 2000; Genia, 2001; Schulte, Skinner, \& Claiborn, 2002; Elmi, 2007, 2013; Hafsa, 2008; Zainab, Wan Ibrahim, \& Elmi, 2012, 2014; Elmi \& Zainab, 2013; Effendi et al., 2016; Shamsiah, Che Zarina, \& Saedah, 2016; Ismail, 2017). Emmons (2000) explained that there was good potential in the SI to solve the problem of spiritual and religious. Emmons' statement was supported by a study by Genia (2001) that found that there was a scale of impact on the assessment of spiritual intelligence in a group of students. Meanwhile, Schulte et al. (2002) described the cultural diversity of religions and spiritual concepts. Makki (2008) found that oral Linguistic intelligence contributes 18.8\% to spiritual intelligence.

A study conducted by Baharuddin (2007), Ismail et al. (2012) and Ismail et al. (2014) noted that there is a relationship between religious knowledge and religious activity among the elderly. In addition, Baharuddin \& Ismail (2013) found that knowledge of the elderly is one of the indicators that can determine a person's spiritual intelligence. In fact, Baharuddin (2013) concludes that Islamic spiritual intelligence is the inner strength of man that comes from the soul, heart, feelings, deep faith, perseverance of practice based on Allah's guidance and good morals. This statement was evidenced by Effendi \& Matore (2015) who found that there is a significant relationship between Adversity Quotient (AQ), which is an individual's ability to cope with challenges, and Spiritual Intelligence among polytechnic students. Fry \& Wigglesworth (2013) also describes the Spiritual Intelligence (SQ) that can strengthen and integrate the Intellectual Quotient (IQ) and Emotional Intelligence (EQ). Meanwhile, Hanefar et al. (2016) synthesized the theme of spiritual intelligence from the Islamic point of view and Western philosophy which has been able to produce a new theoretical framework. Ismail (2017) concludes that every human being has some intelligence, including spiritual intelligence covering aspects of faith and worship.

From these studies, it can be concluded that there is a significant relationship between SI and individual life in terms of intellectual, emotional and religious aspects. In other words, SI is the dominant domain of intelligence in the diversity of human intelligence that can directly or indirectly influence an individual's life.

\section{Spiritual Intelligence in Multiple Intelligence Theory}

At the initial stage, the emergence of SI theory proposed by Gardner (1983), a total of eight intelligences were introduced. Then, in 1999, he was able to identify the ninth intelligence, namely the Spiritual Intelligence. He has interpreted 
this SI into three connotations. First, he refers to cosmic issues or existence. Second, he emphasized SI as an individual's psychological achievement and extraordinary spiritual experience. Third, SI is defined in the social aspect, how one person influences or affects others. It includes these two connotations in their lives (Fry \& Wigglesworth, 2013).

Gardner (2000) described the first SI connotation to refer to an individual's ability to attain a state in which he or she can control himself or herself as having meditation. He considers that this intelligence involves the ability to physiologically control the body. Therefore, he argues that it is more appropriate to label such intelligence as Bodily-Kinesthetic Intelligence (BK).

The second SI connotation is to refer to the individual's ability to reach a state in which he is united with nature and the Creator and to experience a special relationship with God. In the language of Islamic Sufism, the term may be referred to as zouq or fana'. In other words, this definition refers to the feelings experienced by the individual. According to Gardner (2000), the activity involved feeling is something that cannot be measured. For example, if three individuals show the same efficiency in the fields of mathematics, but expressed different feelings about the training given. He emphasized that the expression of feelings was outside the context of intelligence.

Meanwhile, the connotation of the third SI is the social aspect in delivering the two connotations above. This connotation means that individuals with high SI can influence others in exploring cosmic issues. In addition, the individual is also capable of improving the relationship of other individuals with the Creator (Halama \& Strizenec, 2004). However, Gardner (2000) rejected the SI as a kind of intelligence. He argued that the basis for intelligence is the ability to perform measurements. For example, Verbal-Linguistic Intelligence measures sound and language, Visual Spatial Intelligence measures the position and perspective of objects in space and Interpersonal Intelligence assesses the status, attitudes and motivations of other individuals in relation to oneself.

Therefore, Gardner (2000) has labeled this SI as Existential Intelligence. Existential Intelligence is described as an individual that reflects and ponders the fundamental questions of existence (Gardner, 1999). For example, questions like who are humans? Where do humans come from? Why do humans live and die? Thus, he argued that the term is more appropriate because the means in accordance with the nature of human existence as an individual in the cosmos and the human ability to think about this. He also added that this intelligence is highly relevant to the eight other intelligences that he had introduced earlier.

Siti Rahayah et al. (2008) stated that Gardner has not yet confirmed this spiritual intelligence. This is because most elements of spiritual intelligence do not represent cognitive activity (Gardner, 2000). Nonetheless, he believes that when one speaks of spirituality, it means that the individual has the existential intelligence. This statement is supported by Furnham (2009), who stated that Gardner ultimately rejected the existence of two types of intelligence, namely spiritual intelligence and existential intelligence. The rationale is that these two intelligences 
do not meet his "liberal" criteria. In Gardner's definition, intelligence is a biological potential to process information that can be activated in a cultural situation to solve problems or create products with a value in that culture (Furnham, 2009).

Vialle (2007) also agreed with Furnham on Gardner's rejection of existential intelligence. He said Gardner had concluded that the existential intelligence was a spiritual intelligence in a more specific form which required more empirical evidence support.

\section{Spiritual Intelligence Concept from Islamic Perspectives}

Like Western scholars, many Muslim scholars also discuss about SI. Most of them associate SI with the intimacy of an individual to God. In some studies (Ary Ginanjar Agustian, 2001; Muhammad, 2004; Ismail et al., 2011; Baharuddin \& Ismail, 2013), SI is defined as one's ability to achieve excellence in relationships with Allah SWT, fellow human beings and nature by doing good and preventing evil (amr bi al-ma' ruf wa nahy'ani al-munkar).

Whereas, Baharuddin \& Ramli (2014) summarized that SI is the inner strength of man which is the result of spirit, heart, feeling, soul, deep faith, a practice that is based on the law of God and is praised and capable of living life in harmony with the Islamic environment. This opinion is supported by Fallah, Khosroabadi, \& Usefi (2015) found that SI brings man to achieve the pleasure of Allah by means of guiding the hearts of people towards the right path.

In this case, SI refers to the role played by the human heart ( $q a l b$ ). For example, every Muslim is obliged to pray five times a day. A committed Muslim will fulfill this duty of prayer in accordance with the prescribed Islamic shariah. In the practice of prayer, the heart plays a very important role in ensuring a servant's devotion while worshiping the Creator. Fallah et al. (2015) stated that a person who has the SI is a pious and able to manifest good moral in the character and behavior.

\section{Spiritual Intelligence Domain}

The study found that the Spiritual Intelligence (SI) comprises seven domains, which is the spirit (al-ruh), heart (al-qalb), soul (al-nafs), mind (al-aqI), faith, practices and morals. Baharuddin \& Ismail (2015) concluded that this domain is important for Muslims to practice in life as a guide in obeying the Creator, Allah Almighty.

Baharuddin \& Ismail (2015) in their study, outlined the seven domains;

a) The spiritual domain (al-ruh) is defined as the ability of the internal power emitted by the spirit of God that cannot be seen by the human senses and are not bound by the dimensions or size of the material that transcends space and time and distributed throughout the universe (Baharuddin \& Ramli, 2014). Al-Ghazali (1988) divided divides the spiritual domain into two types, namely the elastic mass (jisim latif) and al-latifah al-'alimah al-mudrikah. Elastic mass (jisim latif) means a mass containing black blood originating from the body, then flowing 
through the muscles, bones and blood throughout the body. Life, sensation, sight, hearing and smell originate in this spiritual domain. It acts as a generator for the whole body. Meanwhile, al-latifah al-alimah al-mudrikah is also one of the interpretations of heart (al-qalb). It is the power of God and cannot be understood by the human mind (Al-Ghazali, 1988).

There are many verses in the Quran that explain the meaning of the spiritual domain. Among them is Surah Yasin (40) verse 15 describing the spiritual domain as a matter of Allah SWT and people are ignorant about it. Surah Maryam (19) verse 17 describes the spiritual domain as an angel; Surah al-Shura (42) verse 52 describes the spiritual domain as the Quran. There is a Hadith of the Prophet SAW narrated by Imam Muslim explaining that al-ruh is a spirit that exists in the womb of women. Al-ruh in this Hadith refers to the spirit that begins with the creation of man in the womb; starting from the semen, the blood clots, the bones and the flesh, and then they are wrapped in skin and finally the spirit is blown into the womb. In short, it can be concluded that the spirit is the absolute right and power of Allah Almighty. Humans are only given limited knowledge of the nature of the spirit.

b) The heart domain (al-qalb) is defined as the ability to change one's belief system in order to know Allah Almighty and to fulfill the law of Allah Almighty or vice versa. It is based on the development of the heart (al-qalb) whether one has a good or bad relationship with one's life with Allah Almighty, fellow man and all beings created by Allah Almighty. The heart domain has two senses, namely al-qalb (physical) and al-qalb (spiritual). Al-qalb (physical) is a physical lump of blood in which a black hole contains blood. Whereas, al-qalb (spiritual) is subtle elements, namely latifah Ilahi rabbaniyah rühaniyyah (Al-Ghazali, 1998).

The word Al-qalb can be found in the Quran, surah al-Anfaal (8), verse 2 describes the hearts of believers who fear the greatness and power of Allah Almighty. The description of al-qalb is in the form of positive and negative. For example, description of al-qalb dalam in the form of positive is a good heart (Quran, al-Shu' ara' 26: 88-89), a testable heart (Quran, al-Hujurat 49:3) and the heart that obeys Allah's guidance (Quran, al-Nur 64:11). Whereas, the meaning of al-qalb in the negative form is that the heart can become blind (Quran, al-Hajj 22:46), hard-hearted (Quran, al-Hajj 22:53), the heart that can get sick (Quran, al-Baqarah 2:10), a heart that can be locked to death and rusty (Quran, al-Mutaffifin 83:14; and Quran, al-Baqarah 2: 7), a heart that can follow the whisper of Satan (Quran, al-An'am 6: 113) and a heart that is ignorant (Quran, al-Anfaal 8:24).

There are also some hadiths that mentioned about al-qalb. The hadith narrated by Imam Bukhari explains that the Prophet SAW told about the heart can shape behavior and personality. In addition, Imam Bukhari also narrated a hadith from the Prophet SAW, which stated that whoever has in his heart goodness the weight of aan atom (seed), will be brought out of Hell. In another hadith, narrated by Imam Bukhari, the Prophet SAW said that the heart is obedience to 
Allah Almighty.

In line with Islamic spiritual intelligence, the study found that al-qalb is a domain of spiritual intelligence that can change one's existing belief system to know God and to practice the law of Allah Almighty or vice versa. This is because the change of heart (al-qalb) able to determine the good or bad relationship between a person with Allah Almighty, fellow man and all creation of Allah Almighty. In short, it can be concluded that the heart domain (al-qalb) is an element that can generate good or bad personality in a person.

c) The soul domain (al-nafs) defined as the ability to make one good and obedient to the law of Allah SWT or bad and disobey Allah's command based on evil spirits (al-nafs al-ammarah bi al-su'), a soul that cannot attain perfect peace, but continues to fight against lust (al-nafs al-lawwamah) and noble soul (al-nafs al-mutmainnah) (Baharuddin \& Ramli, 2014). In short, the three types of souls in this spiritual intelligence are between the two extremes; evil and noble. Therefore, in order to find peace in the domain of the soul, Allah Almighty commands believers to always remember Him. Four approaches to remembering Allah Almighty, by performing prayers five times a day, remembering the blessings He has bestowed, keeping the promises of Allah SWT to mankind and constantly reciting the Quran (Elmi Baharuddin \& Zainab Ismail, 2015).

There are many verses in the Quran that explain the meaning of the soul domain (al-nafsu). For example, Al-nafsu, a soul that can lead to error and fear (Quran, al-Shams 91: 7-10); Al-nafsu those who fear the greatness of Allah Almighty and refrain from the pleasure of doing evil (Quran, al-Nazi at 79:40); Al-nafsu as the soul which is in line with the desire of the human lust is forbidden by Allah Almighty (Quran, al-Nisa' 4:27); Al-nafsu as a cruel man (Quran, al-Qasas 28:50); as a person without the guidance of Allah Almighty (Quran, al-Rum 30:29); and al-nafsu as a person who wishes to oppose his heart and hearing (Quran, al-Jāthiyyah 45:23).

In short, the soul domain al-nafsu in spiritual intelligence has the ability to do good and obey or do evil and disobey the law of Allah Almighty. This is because there are three types of lust in the human body, namely al-nafsual alammara bi al-su', al-nafsu al-lawwamah and al-nafsu al-Mutmainnah. To prevent the soul being directed to al-nafsu al-ammara bi al-su' and al-nafsu al-lawwamah and obtain al-nafsu al-Mutmainnah, Muslim individuals must purify the soul domain (al-nafsu) by obeying the Islamic law, abandoning the prohibition of Allah Almighty, al-zikr to remember Allah and adopting the recommended behavior in everyday life.

d) The sense domain (al'aqI) is defined as the ability to imagine and reflect on the greatness and power of Allah Almighty. At the same time, the domain of reason builds the human SI to lead humans to govern and manage nature with the guidance and advice of Allah Almighty to conform to the purpose and goals of human creation (Baharuddin \& Ramli, 2014).

Sense is fundamental to humanity. By using that, the position of humans and other beings can be distinguished. It is also the main and fundamental concept 
that causes the person to accept responsibility and the conditions of one's perfection. Therefore, Allah grants the human sense as a great favor and mercy. Therefore, Islam strictly forbids acts of damaging mental health, such as drinking alcoholic beverages and drug addiction. In another hadith, the Prophet SAW said about the significance of mind, as narrated by al-Tabarani:

Meaning: Aisyah reported, "When I asked the Propeht, "Oo Messenger of AIlah; with what is man different from his advantage in the life of the world?" He replied," In a sense. "I asked," What about the hereafter? Is not the man rewarded according to their deeds? "The Messenger of Allah (May peace be upon him) replied: They do not practice according to the intellect that Allah Almighty has given them. Therefore, their practices are according to their level of sense and according to the rate they are rewarded."

According to these principles, the sensible mind is a condition of the covering and one is charged with responsibility, both in matters of faith and worship. Therefore, in a sense, humans are free to choose their ways, whether they are disbelievers or believers. Baharuddin \& Ismail (2015) explained that the domain al-aql enables people to measure SI whether he thinks something in the world to glorify Allah Almighty or vice versa, as Allah Almighty says in the Quran, al-Alaq (96) verse 1 to 5. In short, the domain al-aql is a source of strength for imagining and thinking about the greatness and power of Allah Almighty, thus nurturing the human SI. Human life would be more meaningful if they used the domain al-aql in self-management, family, community and country based on Islamic truth.

e) The faith domain is defined as the ability of a person to know Allah SWT as his Creator, believing, virtuous and refined in heart before obeying Allah's command and seeking forgiveness from Allah Almighty. There are several passages from the Quran regarding the faith domain (Quran, Muhammad (47): 19, Quran, Taha (20): 13-14). Hamka (1999) explained verse 19 in the Quran, $M u$ hammad (47), it is about the true practice of faith. He explained that the first duty of a Muslim is to have knowledge and experience before speaking about Islam. In addition, Muslims are encouraged to remember and pray to Allah.

In other words, the faith domain refers to trust in God. This belief includes the belief in the existence of things, the nature and deeds of God, the truth of the Prophet, the belief in all things heard through the teachings of the religious faith, such as heaven and hell and the belief in the pillars of Islam. In conclusion, faith is a domain of reference to spiritual intelligence, an ability to acknowledge God's power and position in daily life.

f) The worship domain is defined as one's ability to carry out all the commands of Allah Almighty and abandon all His prohibitions in carrying out the demands of religious practice in daily life. Baharuddin and Ismail (2015) stated that the indicator of worship is religious practice. The word ibadah comes from the Arabic word "abda" which means slave. Thus, worship is a form of obedience and respect for a person to his God after believing that he is only a helpless and weak servant. Any form of obedience to God because obedience and 
humiliation are considered worship (Masroom \& Dagang, 2013).

Worship is divided into two types, namely, special worship (khassah), namely prayer, fasting, zakat and pilgrimage. This is the main worship in which the conditions and their implementation have been set by Allah Almighty. Next, general worship ('ammah) such as drinking, eating, and working for a living. This worship refers to all acts of kindness and good faith in Allah Almighty.

Al-Qaradawi (2001) in Baharuddin \& Ismail (2015), stated that worship is prayer, alms, fasting, performing Hajj, speaking the truth, holding charity deeds, doing good to parents, maintaining a relationship of friendship, upholding the promise, refrain from doing wrong, jihad against infidels and hypocrites, do good to neighbors, orphans, the poor, do good to humans and animals, pray and reading the Quran. Thus, this domain of worship can improve one's piety $(\mathrm{Qu}-$ ran, $\mathrm{Al} \mathrm{Imran} \mathrm{3:8).} \mathrm{In} \mathrm{addition,} \mathrm{this} \mathrm{domain} \mathrm{is} \mathrm{an} \mathrm{SI} \mathrm{indicator} \mathrm{among} \mathrm{believers.}$

g) The moral domain is defined as a person's ability to express the personality of the good and leave the bad behavior that stems from spiritual soul (Baharuddin \& Ramli, 2014). Al-Ghazali (1988) stated that morals and manners actually reflect the state of the soul (ruhiyyah). Good character and integrity are manifestations of SI. Meanwhile, bad behavior is the result of a dirty heart that exists in every human being (Al-Ghazali, 1988).

In other words, the moral domain through the spirit domain (al-ruh) which is part of the SI, can be measured by one's ability to act through good behavior. Baharuddin \& Ismail (2015) stated that moral domains can increase public awareness of human nature that has three different characteristics to each other according to one's situation. The first characteristic is a person who has al-nafs al mutmainnah, which is a person who always at peace in obeying Allah and overcoming his desire (Quran, al-Fajr 89: 27-28). Such individuals are those who accept all of Allah's destiny.

The second characteristic of the human character is the reference to the person who has al-nafs al-lawwamah, which is a person who cannot attain perfect peace, but continues to fight lust, as Allah says in the Quran, al-Qiyamah (75), verse 2. In addition, al-nafs al-lawwamah always seeks perfection for good or bad. Whereas, the third character is al-nafs al-ammara bi al-su', which is a person who always follows his evil desires (Quran, Yusuf (12), verse 53). This level of human desire is discussed more fully and in detail in the book of Sufism.

In conclusion, Spiritual Intelligence in Islam refers to the ability of individuals to give meaning based on faith and piety to Allah Almighty. This can be realized by practicing these seven SI domains in relationships, either vertically (human with God) or horizontal (human with the creature of God), to achieve happiness in the world and the hereafter.

\section{Recommendations and Implications}

The Multiple Intelligence Theory (MI) presented by Gardner $(1983,1999)$ has been widely used throughout the world, including Malaysia, in various fields. The same goes for education. In Malaysia, MI theory implemented in primary 
schools in psychometric test called Aptitude Test was conducted on students in Year Three and Year Six. This test aims to identify the tends, strengths or weaknesses, interests, talents and levels of student readiness. In addition, this test also measures innate ability and acquired ability such as personality, career interests, aptitude or ability, problem solving skills and student thinking skills (Kementerian Pendidikan Malaysia). Therefore, this test involves the measurement of all MI constructs including SI, which is labeled as Existential Intelligence.

Gardner (1999) used existential terms to replace spirituality as a problematic connotation (Gardner, 1999). According to him, spirituality is more related to religion and divinity (Halama \& Strizenec, 2004). Based on this statement, Halama \& Strizenec (2004) considered that religious and divine issues are not properly associated with the SI concept because they cannot be clearly explained. Thus, Gardner argued that the concept of existential intelligence is more accurate because the concept has been covering the spiritual aspect.

In addition, Gardner also emphasized that SI does not involve cognitive activity, but only emotion, which is something that cannot be measured. In fact, based on his understanding, the basis of the concept of intelligence is the ability to conduct any form of measurement (Gardner, 2000). Accordingly, Gardner rejected the concept of Spiritual Intelligence and replaced it with the broader concept of Existential Intelligence.

Halama \& Strizenec (2004) stated that Gardner defined the Existential Intelligence as the ability of an individual to position himself or herself to understand the issues of cosmic and human existence. However, Gardner is still not convinced to validate this Existential Intelligence as the ninth intelligence due to the lack of solid evidence of brain structure and measurement processes involved in evaluating this intelligence (Gardner, 2000). This statement was supported by Siti Rahayah et al. (2008). Therefore, Gardner (2000) jokingly stated that the Existential Intelligence is "the $8 \frac{1}{2}$ intelligence. This shows that Gardner himself was not sure about SI and Existential Intelligence he pioneered. Nonetheless, the statement does not mean that he completely rejected it, but opened the door to another more comprehensive and in-depth scientific study.

In Islam, Spiritual Intelligence consists of seven domains, namely, the spirit (al-ruh), heart (al-qalb), soul (al-nafs), mind (al'aql), faith, practice and morals (Baharuddin \& Ismail, 2015). All of these domains are related to each other. This means that when the domain of heart (al-qalb) changes in the positive way, the other domains also tend to be positive and vice versa. For example, a person with a good heart will surely radiate goodness to his soul, mind, faith, practice and morals. Abdullah (2012) pointed out that spiritual intelligence involves the study of the nature and tendency of the human psyche that includes all aspects of life which is manifested in a meaningful and prosperous life. These domains are widely mentioned in the Quran and the hadith.

On the whole, the concept of SI in Islam refers to the inner strength of man that comes from spirit, heart, soul, mind, deep faith, perseverance in practice 
based on God's command and noble morals. Not only that, this intelligence refers to the human ability to maintain a good relationship with God, fellow human beings and nature as a whole. Therefore, these seven domains need to be developed and practiced literally to create individuals and societies with Islamic Spiritual Intelligence. This is in line with the views of the Quran, Hadith, experts, Islamic and Western psychologists, spiritual experts and contemporary researchers.

\section{Conclusion}

From an Islamic perspective, there is no contradiction at all in eight domains of SI theory, but it is widely explained in Quran, Hadith and Muslim scholarly opinion, especially in the field of Sufism. However, the understanding of SI construction is necessarily different from western theory, especially Gardner because the West is generally limited to secularism which does not associate religion and spirituality with worldly affairs. This is the main point of difference between Islam and the West. From a Western perspective, especially the founder of SI theory, Gardner considers this SI construct unacceptable as a form of intelligence. Rationally, this intelligence cannot be measured and does not involve cognitive activity, but only emotion (feelings).

Islam is a comprehensive religion built on 3 fundamentals; namely, Islam (the outward and ascetic practice found in the 5 Pillars of Islam), Faith (the practice of the heart, involving the heart and belief of the 6 Pillars of Faith), Virtue (the essence of Islam and Faith in connection with spirituality and affirming the truth outward and hearty practices). So, there is no separation between daily affairs and practices with regard to heart and spirituality because no matter how small the outward actions or trajectories, they will be held accountable in the hereafter. From the descriptions and conclusions above, it can be concluded that the concept of SI in Islam clearly states the relationship between man and religion and god. This concept can be realized through seven domains; namely spirit (al-ruh), heart (al-qalb), soul (al-nafs), mind (al-'aqI), faith, practice and morals. If the individual owns the domain in a positive way, then the individual is able to build his or her identity as a great Muslim. On the other hand, if an individual has such a domain in a negative way, it will contribute to an unwanted person by religion, society and country.

As the "Master Teacher" in SI theory, Gardner does not completely reject the concept of SI. He labeled SI as the 8th domain. It can be concluded that Gardner himself opened the definition and dimensions of SI to a more comprehensive and holistic debate and study. This is a challenge for Muslim scholars to highlight the truth of SI theory from an Islamic perspective as a missionary responsibility. In addition, SI constructs should be taken not only as a theory, but as a domain that supports all MI domains to be practiced in society. Furthermore, the adoption of a strong SI structure in the field of education in particular will enable the National Philosophy of Education to produce citizens who are know- 
ledgeable, skilled, virtuous, responsible and capable of achieving personal wellbeing.

\section{Funding}

This research was supported by the Universiti Kebangsaan Malaysia under grant of UKM PP-FPEND-2019.

\section{Conflicts of Interest}

The authors declare no conflicts of interest regarding the publication of this paper.

\section{References}

Abdullah, F. (2012). Teaching Islamic Ethics and Ethical Training: Benefiting from Emotional and Spiritual Intelligence. International Journal of Humanities and Social Science, 2, 224-232.

Agustian, A. G. (2001). Rahsia sukses membangun kecerdasan dan spiritual ESQ: Emotional Spiritual Quotient berdasarkan 6 rukun iman, dan 5 rukun Islam. Jakarta: Penerbit Arga.

Al-Ghazali, A. H. M. (1988). Ihya ulum al-din. Singapura: Pustaka Nasional.

Al-Qardhawi, Y. (2003). Sunnah: Sumber ilmu dan peradaban. Selangor: International Islamic Thought Malaysia.

Ariffin, R., \& Ismail, H. N. (2007). Konsep Keadilan dalam Teori Kecerdasan Pelbagai Menurut Perspektif Islam. Pendidikan Psikologi, 7, 66-73.

Arifin, S. R., Arifin, R., \& Makki, H. M. (2008). Faktor kontribusi kecerdasan pelbagai dalam kalangan pelajar remaja. Jurnal Pendidikan, 33, 35-46.

Baharuddin, E. (2007). Penyertaan warga tua Rumah Seri Kenangan Cheras, Selangor terhadap aktiviti agama. Master Thesis, Bangi: Fakulti Pengajian Islam, Universiti Kebangsaan Malaysia.

Baharuddin, E. (2013). Kecerdasan ruhaniah dan amalan agama di rumah kebajikan. PhD Thesis, Bangi: Fakulti Pengajian Islam, Universiti Kebangsaan Malaysia.

Baharuddin, E., \& Ismail, Z. (2013). Hubungan Kecerdasan Ruhaniah WargaTua dengan Ama lan Agama di Rumah Kebajikan. Jurnal Islamiyyat, 35, 19-28.

Baharuddin, E., \& Ismail, Z. (2015). 7 Domains of Spiritual Intelligence from Islamic Perspective. Procedia-Social and Behavioral Sciences, 211, 568-577. https://doi.org/10.1016/j.sbspro.2015.11.075

Baharuddin, E., \& Ramli, Z. (2014). Definisi dan Konsep Kecerdasan Ruhaniah MenurutPer spektif Sarjana Islam. Jurnal Penyelidikan Islam JAKIM, 26, 49-61.

Cohen, R., \& Swerdlik, M. (2009). Psychological Testing and Assessment: An Introduction to Tests and Measurement (7th ed.). New York: McGraw Hill.

Effendi, M., \& Matore, E. M. (2015). Pembinaan instrumen kecerdasan cabaran (IKBAR) bagi pelajar politeknik menggunakan Model Rasch. PhD Thesis, Universiti Sains Malaysia.

Effendi, M., \& Matore, E. M. (2019a). Structural Equation Model (SEM) in Assimilating EQ, SQ and AQ for Mechanical Students Context. In Proceedings of Mechanical Engineering Research Day (pp. 230-231). Melaka: Universiti Teknikal Malaysia Melaka.

Effendi, M., \& Matore, E. M. (2019b). The Impact of EQ, SQ and IQ towards AQ Using 
Path Analysis and Rasch Logit for Modelling Purpose among Mechanical Engineering Students. In Proceedings of Mechanical Engineering Research Day (pp. 225-226). Melaka: Universiti Teknikal Malaysia Melaka.

Effendi, M., Matore, E. M., \& Khairani, A. Z. (2016). Correlation between Adversity Quotient (AQ) with IQ, EQ and SQ among Polytechnic Students Using Rasch Model. Indian Journal of Science and Technology, 9, 1-8. https://doi.org/10.17485/ijst/2015/v8i1/108695

Effendi, M., Matore, E. M., Khairani, A. Z., Maat, S. M., Ahmad, N. A., \& Matore, E. R. M. (2018). The Influence of Intellectual Quotient (IQ), Emotional Quotient (EQ) and Spiritual Quotient (SQ) against Adversity Quotient (AQ) on Polytechnic Students in Malaysia. Journal of Engineering Science and Technology, 83-91.

Effendi, M., Matore, E. M., Khairani, A. Z., Razak, N. A., \& Maat, S. M. (2018). Assessing the Quality of Items Measuring Adversity Quotient among Mechanical Engineering Students Using Rasch Model. In Proceedings of Mechanical Engineering Research Day (pp. 189-190). Durian Tunggal: Faculty of Mechanical Engineering, Universiti Teknikal Malaysia Melaka.

Emmons, R. A. (2000). Is Spirituality an Intelligence? Motivation, Cognition, and the Psychology of Ultimate Concern. International Journal for the Psychology of Religion, 10, 3-26. https://doi.org/10.1207/S15327582IJPR1001_2

Fallah, V., Khosroabadi, S., \& Usefi, H. (2015). Development of Emotional Quotient and Spiritual Quotient: The Strategy of Ethics Development. International Letters of Social and Humanistic Sciences, 49, 43-52.

https://doi.org/10.18052/www.scipress.com/ILSHS.49.43

Fry, L. W. J., \& Wigglesworth, C. G. (2013). Toward a Theory of Spiritual Intelligence and Spiritual Leader Development. International Journal on Spirituality and Organization Leadership, 47, 1-41.

http://iispiritualleadership.com/wp-content/uploads/docs/SpiritIn telAOM2010.pdf

Furnham, A. (2009). The Validity of a New, Self-Report Measure of Multiple Intelligence. Current Psychology, 28, 225-239. https://doi.org/10.1007/s12144-009-9064-Z

Gardner, H. (1983). Frames of Mind: A Theory of Multiple Intelligences. New York: Basic Books.

Gardner, H. (1993). Multiple Intelligences: The Theory in Practice. New York: Basic Books.

Gardner, H. (1999). Intelligence Reframed: Multiple Intelligences for the 21st Century. New York: Basic Books.

Gardner, H. (2000). Commentary a Case against Spiritual Intelligence. International Journal, 10, 27-34. https://doi.org/10.1207/S15327582IJPR1001_3

Genia, V. (2001). Evaluation of the Special Wellbeing Scale in a Sample of College Students. The International Journal for the Psychology of Religion, 11, 25-33. https://doi.org/10.1207/S15327582IJPR1101_03

Halama, P., \& Strizenec, M. (2004). Spiritual, Existential or Both? Theoretical Considerations on the Nature of Higher Intelligences. Studia Psychologica, 46, 239-252.

Hanefar, S. B., Sa'ari, C. Z., \& Siraj, S. (2016). A Synthesis of Spiritual Intelligence Themes from Islamic and Western Philosophical Perspectives. Journal of Religion and Health, 55, 2069-2085. https://doi.org/10.1007/s10943-016-0226-7

Ismail (2017). Kecerdasan IQ, EQ dan SQ dalam pembentukan keperibadian mukmin. Kabilah, 2, 159-175. https://doi.org/10.35127/kbl.v2i1.3105

Ismail, Z., Ahmad, W. I. W., \& Baharuddin, E. (2012). Religious Participation among the 
Older Persons in Malaysia. Advances in Natural and Applied Sciences Journal, 6, 388-391.

Ismail, Z., Ahmad, W. I. W., \& Baharuddin, E. (2014). The Commitment of Older Persons in Nursing Homes in Religious Activities. Middle East Journal of Scientific Research, 20, 1734-1737.

Ismail, Z., Ahmad, W. I. W., Rahman, A. A., Endot, I., Mohamad, S. N., \& Baharuddin, E. (2011). Tahap kecerdasan rohani warga tua Seri Kenangan Taman Kemumin dalam dunia komtemparori. In Kertas kerja International Seminar on Da'wah. Anjuran Jabatan Dakwah dan Kepimpinan, Universitas Negeri Jakarta, Institut Kajian Rantau Asia Barat dan Kumpulan Dakwah, Kerohanian dan Pembangunan Islam.

Kementerian Pendidikan Malaysia (n.d.). Pelaksanaan psikometrik (PPsi) sekolah rendah jurulatih utama kerjaya \& psikometrik. http://jpnselangor.moe.gov.my/jpns/images/pdf/spp/psikometrik\%20sek\%20ren.pdf

Makki, H. M. (2008). Kecerdasan Pelbagai dalam kalangan pelajar dan faktor penyumbang bagi domain MyMICA. Master Thesis, Bangi: Fakulti Pendidikan, Universiti Kebangsaan Malaysia.

Masroom, M. N., \& Dagang, W. I. W. (2013). Peranan ibadah terhadap kesihatan jiwa (pp. 1-9). Islam.

Muhammad, D. S. (2004). QQ membentuk kecerdasan daripada Quran. Jakarta: Hikmah.

Pasiak, T. (2008). Revolusi IQ, EQ, SQ. Kuala Lumpur: PTS Millennia Sdn. Bhd.

Safara, M., \& Bhatia, M. S. (2013). Commentary on Spiritual Intelligences. Delhi Psychiatry Journal, 16, 412-422.

Schulte, D. L., Skinner, T. A., \& Claiborn, C. D. (2002). Religious and Spiritual Issues in Counseling Psychology Training. The Counseling Psychologist, 30, 118-134.

https://doi.org/10.1177/0011000002301009

Spearman, C. (1904). General Intelligence; Objectively Determined and Measured. The American Journal of Psychology, 15, 201-292. https://doi.org/10.2307/1412107

Vialle, W. J. (2007). Spiritual Intelligence: An Important Dimension of Giftedness. In K. Tirri (Eds.), Values and Foundations in Gifted Education (pp. 171-186). Bern: Peter Lang.

Zohar, D., \& Marshall, I. (2000). Spiritual Intelligence: The Ultimate Intelligence. London: Bloomsburry. 